
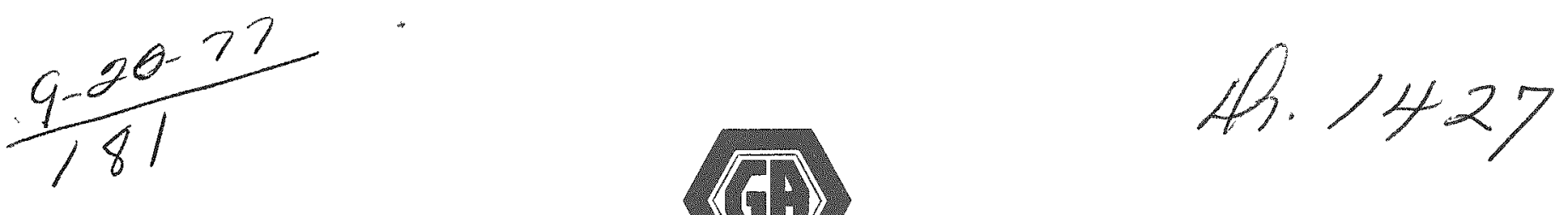

\title{
SAFETY ASPECTS OF SOLVENT NITRATION IN HTGR FUEL REPROCESSING
}

\author{
GA-A 14372 \\ UC-77
}

\author{
by \\ R. G. WILBOURN
}

Prepared under

Contract EY-76-C-03-0167

Project Agreement No. 53

for the San Francisco Operations Office

U.S. Energy Research and Development Administration 


\section{DISCLAIMER}

This report was prepared as an account of work sponsored by an agency of the United States Government. Neither the United States Government nor any agency Thereof, nor any of their employees, makes any warranty, express or implied, or assumes any legal liability or responsibility for the accuracy, completeness, or usefulness of any information, apparatus, product, or process disclosed, or represents that its use would not infringe privately owned rights. Reference herein to any specific commercial product, process, or service by trade name, trademark, manufacturer, or otherwise does not necessarily constitute or imply its endorsement, recommendation, or favoring by the United States Government or any agency thereof. The views and opinions of authors expressed herein do not necessarily state or reflect those of the United States Government or any agency thereof. 


\section{DISCLAIMER}

Portions of this document may be illegible in electronic image products. Images are produced from the best available original document. 
GA-A 14372

UC-77

\title{
SAFETY ASPECTS OF SOLVENT NITRATION IN HTGR FUEL REPROCESSING
}

\author{
by \\ R. G. WILBOURN \\ Prepared under \\ Contract EY-76-C-03-0167 \\ Project Agreement No. 53 \\ for the San Francisco Operations Office \\ U.S. Energy Research and Development Administration

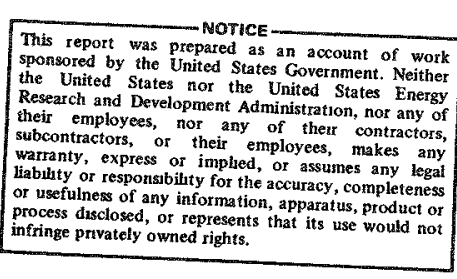 \\ This report was prepated as an account of work
sponsored by the United States Government. Neither \\ their employees, nor any \\ Wheantractors, or their employecs, contractors, \\ mes any ley \\ ot useful of any infor the accuracy, completeness \\ infringe provatedy of represents that its use would not
}

GENERAL ATOMIC PROJECT 3225

DATE PUBLISHED: JUNE 1977 


\begin{abstract}
Reprocessing of HTGR fuels requires evaporative concentration of uranium and thorium nitrate solutions. The results of a bench-scale test program conducted to assess the safety aspects of planned concentrator operations are reported herein.
\end{abstract}




\section{SUMMARY}

Tributyl phosphate (TBP) solvent extraction will be used for the separation of uranium and thorium from fission products in spent HTGR fuel. reprocessing. The Acid-Thorex process will be used for the combined Th/ U-233 fertile and U-233 fissile dissolver solutions and a modified Purex process will be used for the U-235 fissile solutions.

Both the modified Purex and Acid-Thorex solvent extraction flowsheets specify heavy metal concentration steps using evaporators. The concentration steps are required to reduce acidity levels and solution volumes prior to further processing or product storage. In previous work with the Purex process, vigorous reactions were encountered during the uranium concentration operations, resulting in equipment loss and presenting a hazard to personne1.

This report covers the bench-scale experimentation performed at General Atomic Company to assess the potential for the occurrence of a rapid, exothermic reaction in planned heavy metal concentrator operations. The benchscale work was done to serve as a guide for expected behavior of the thorium nitrate/solvent system in pilot and engineering scale concentrators under normal flowsheet operation, as well as extreme conditions potentially arising from inadvertent concentrator maloperation.

Based on data obtained from bench-scale experiments, the following conclusions were drawn:

1. The hydrocarbon diluent employed has an important role in solvent nitration.

2. The normal paraffin hydrocarbon diluent, i.e., $\mathrm{NPH}$, currently being used in pilot plant HTGR fuel reprocessing studies is more 
resistant to nitration than diluents used in early plant applications of the Purex process. "Red-oil" (an organic phase mixture of heavy metal nitrate and organic decomposition products) was not formed in tests using TBP/NPH as the solvent system during concentration of thorium and uranyl nitrate solutions under literature conditions reported to produce "red-oil" with a previously employed diluent.

3. No vigorous, uncontrolled reactions were observed for the TBP/NPH thorium nitrate system or the TBP/NPH urany1 nitrate system at temperatures to $150^{\circ} \mathrm{C}$ under experimental conditions described herein.

4. With suitable concentrator design (to control foaming and to vent flammable gases), an inadvertent temperature excursion to $150^{\circ} \mathrm{C}$ does not constitute an undue safety hazard, if a nitration-resistant diluent is used. 


\section{INTRODUCTION}

Two processes, i.e., Purex (Ref. 1) and Acid-Thorex (Ref. 2), are used in nuclear fuel reprocessing applications. The Purex process was developed for the separation and recovery of fissionable isotopes in uranium-plutonium reprocessing campaigns. The Acid-Thorex process was developed for the reprocessing of thorium-uranium based nuclear fuels.

Tributy 1 phosphate is the extractant employed in both the Purex and Acid-Thorex solvent extraction processes for heavy metal-fission product separation. The extractant is generally used in a kerosene diluent to reduce the density and viscosity of the extractant and to enhance aqueous/ organic phase separation. The TBP/diluent system is common1y referred to as the process solvent. Many kerosene-type diluents have been used over the years, and Tables $A, B$, and $C$ in the Appendix contain the physical and chemical properties of some of these diluents. Inertness of the diluent toward chemical reactions with process materials and radiation, as well as cost, are major considerations in the selection of the diluent.

The most obvious effect of diluent degradation due to nitration in solvent extraction process applications is a marked reduction in observed heavy metal - fission product decontamination factors (DFs). The deleterious DFs observed in processes with degraded solvents are due partly to the formation of ligands which complex with fission products, e.g., zirconium, and are soluble in the solvent phase. Experiments conducted at Savannah River (Ref. 3) have shown n-dodecane to be the most nitration-resistant diluent among a group of normal and isoparaffin hydrocarbons tested. The nitration stability of $n$-dodecane was found to be 20 to 30 times greater than the purified kerosene diluent "U1trasene" used in early solvent extraction work (see Table $A$ in the Appendix). Degraded solvents also show poor phase separation and decreased mass transfer coefficients for 
uranium and thorium. Consequently, nitration-resistant diluents have been identified and used in more recent solvent extraction operations (Ref. 4).

The present work has shown diluent nitration resistance to be an important consideration in the safe operation of heavy metal concentrators. Figures 1 and 2 contain simplified flowsheets for the modified Purex and AcidThorex processes. Heavy metal concentration is a requirement common to both flowsheets.

In earlier Purex process work (Refs. 5, 6), vigorous, exothermic reactions were encountered during concentration of urany 1 nitrate product. Previously reported concentrator incidents have four features in common: (a) solvent was present in the concentrate; (b) concentration had proceeded to the point of incipient calcination of the uranyl nitrate (temperatures above $135^{\circ} \mathrm{C}$ ); (c) the explosion, or rapid reaction, involved the evolution of nitrogen oxides; and (d) "red-oil" was found on subsequent examination of concentrator contents (Ref.7).

As a result of the rapid, exothermic reactions encountered in the concentration of uranyl nitrate in the Purex process, maximum concentrator operating temperatures were routinely restricted to $135^{\circ} \mathrm{C}$. In addition, laboratory studies were undertaken at both Savannah River (Ref. 5) and Hanford (Ref. 8) to determine the conditions necessary for "red-oil" formation and rapid reactions between Purex process solvent and uranyl nj.trate solutions containing nitric acid. The formation of "red-oil" is a precursor of vigorous, exothermic reactions in concentrator operations (Ref. 9). Experiments were also performed at Hanford (Ref. 10) with the plutonyl nitrate/solvent system with similar results; however, no experiments were performed with the thorium nitrate system.

In the tests conducted at Hanford (Ref. 8), "red-oil" formation was observed on refluxing of $1.1 \underline{M}$ nitric acid containing $0.1 \underline{M}$ uranyl nitrate with 30 volume percent TBP/diluent for 72 hours. The diluent used in the 


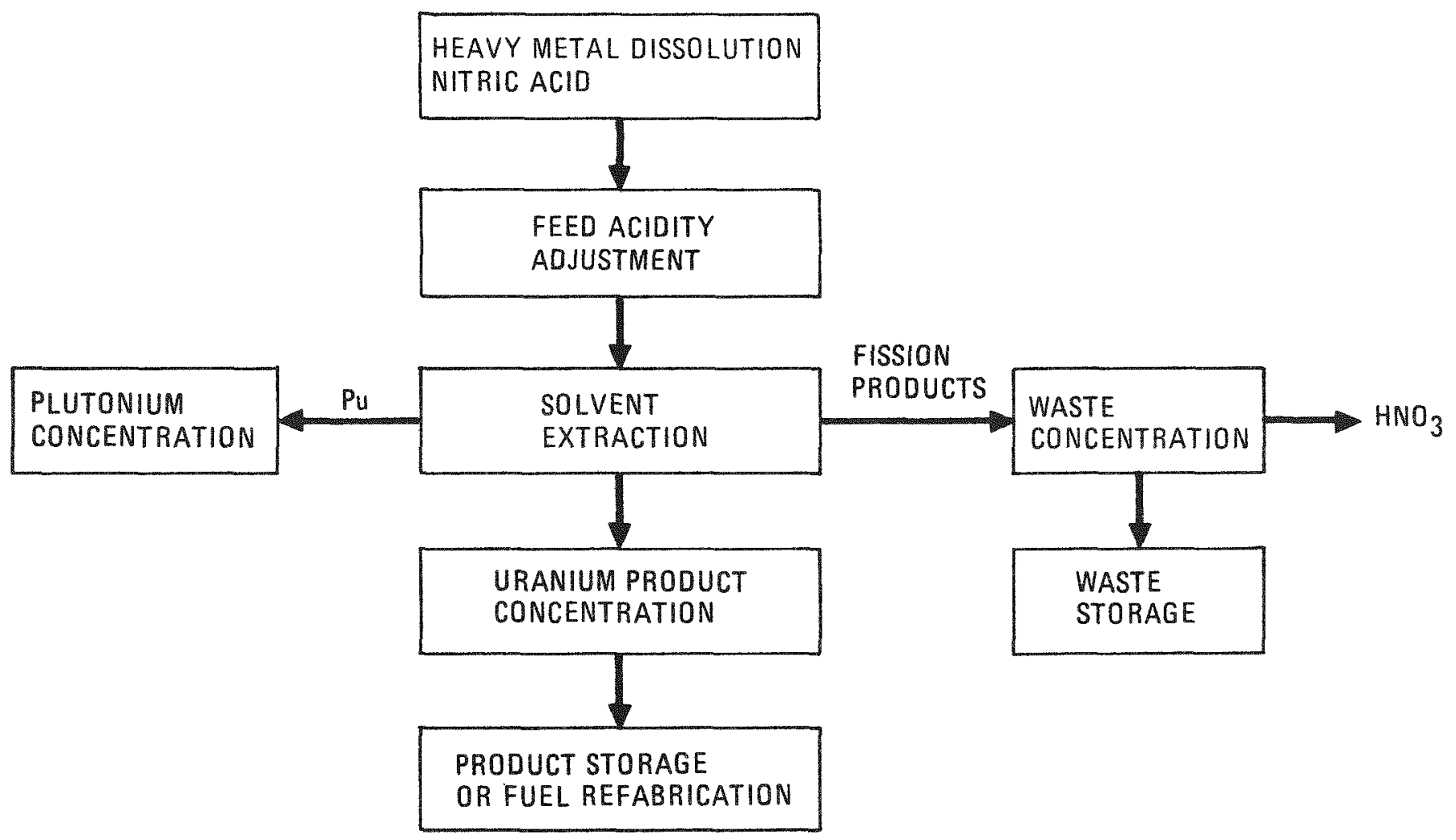

Fig. 1. Modified Purex process - simplified flowsheet 


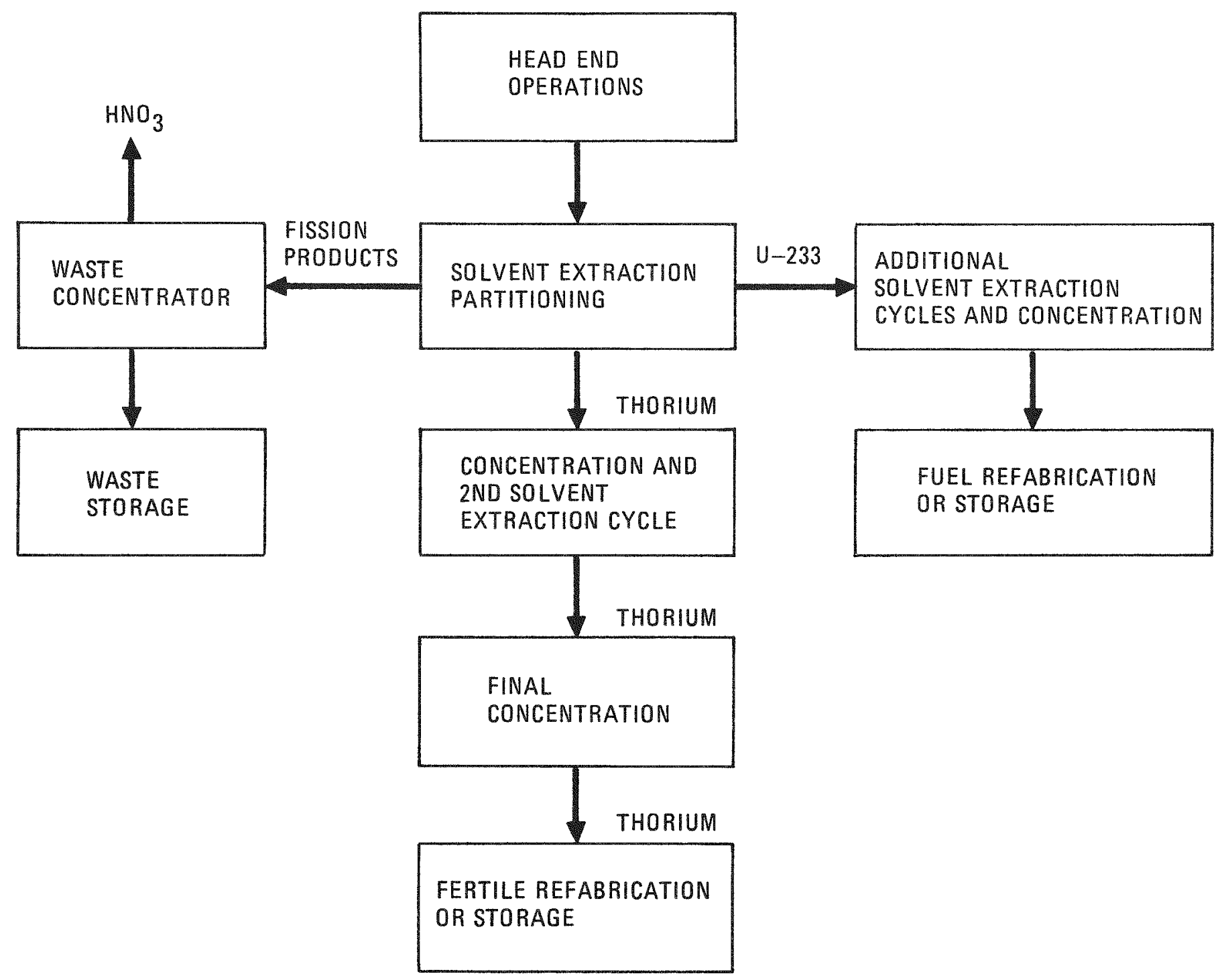

Fig. 2. Acid-Thorex process - simplified flowsheet, Th/U-233 fertile stream 
Hanford solvent extraction operations and subsequent laboratory work was She11 Deodorized Spray Base (see Table A in the Appendix).* No 1iterature reports of "red-oil" formation could be found in which the solvent system was composed of TBP/NPH.

A bench-scale experimental study was undertaken at General Atomic Company in an effort to establish conditions for "red-oil" formation or vigorous, exothermic reactions with the currently used diluent, i.e., South Hampton Company $\mathrm{NPH}, * *$ and Chevron Deodorized Spray Base Solvent 450 ." The physical properties of these diluents are given in Tables $A$ and $B$ in the Appendix. The tests consisted of heating various mixtures of uranyl and thorium nitrate solutions with solvent and monitoring reaction rates as a function of time. Al1 tests were performed at atmospheric pressure. Tests were not performed with Shell Deodorized Spray Base diluent used in previous work (Ref. 8) because the material is currently unavailable.

*A product of She11 011 Company. $* *$ A product of South Hampton Company, Silsbee, Texas. $* * *$ A product of Standard $0 i 1$ Company of California. 


\section{EXPERIMENTAL AND RESULTS}

\subsection{OPEN CUP EXPERIMENTS}

Several nitration experiments were performed in $25 \times 50 \mathrm{~mm}$ open glass cups. A sand bath and a phosphoric acid bath were used to heat the cups and contents on a hot plate under controlled conditions. Time and temperature data were taken during heat-up and any visual evidence of a rapid reaction was noted. A slow evolution of $\mathrm{NO}_{2}$ was observed in a11 open cup experiments on heating to $>125^{\circ} \mathrm{C}$.

Data collected for diluent only (no TBP content) in contact with $1 \mathrm{M}$ uranium or thorium nitrate in Thorex dissolver solution $\left(9 \underline{\mathrm{M}} \mathrm{HNO}_{3}, 0.1 \underline{\mathrm{M} \mathrm{AI}}{ }^{+3}\right.$, $0.05 \mathrm{M} \mathrm{F}^{-}$) appear in Table 1. The greater susceptibility of Chevron Deodorized Spray Base Solvent 450 to nitration, as opposed to NPH, is readily apparent in the results shown in Table 1.

Data are summarized in Table 2 for experiments in which thorium nitrate-nitric acid-30\% TBP/diluent mixtures prepared at ambient temperatures were quickly immersed in open cups into a phosphoric acid bath at $138^{\circ} \mathrm{C}$ (these experiments were designed to simulate the sudden introduction of organic material into a concentrator under inadvertent maloperation). Results presented in Table 2 indicate that temperatures we11 in excess of $150^{\circ} \mathrm{C}$ were required for rapid reaction with heavy metal-TBP/NPH systems.

Additional experiments were conducted by insertion of open cups containing 30\% TBP/diluent organic phases following equilibration with $1 \underline{\mathrm{M}}$ thorium/uranium Thorex solutions into a preheated aluminum block $(7.6 \mathrm{~cm}$ x $5.1 \mathrm{~cm} \times 5.1 \mathrm{~cm}$ ) machined to receive the cups (see Fig. 3). This method was used to test samples of Conoco $\mathrm{C}_{12} \mathrm{C}_{14}$ and Texaco $\mathrm{P}-4^{* *}$ normal paraffin

$*$ A product of Continental oil Company. $* *$ A product of Texaco. 
TABLE 1

DILUENT NITRATION STUDY - DATA SUMMARY

\begin{tabular}{c|c|c}
\hline $\begin{array}{c}\text { Time } \\
(\text { min })\end{array}$ & $\begin{array}{c}\text { Temperature } \\
\left({ }^{\circ} \mathrm{C}\right)\end{array}$ & Observation \\
\hline 0 & 25 & \\
12 & 59 & \\
17 & 75 & \\
22 & 86 & Yellow discoloration - Spray Base samples \\
24 & 91 & No 2 evolution - Spray Base samples \\
27 & 99 & \\
37 & 108 & Incipient foaming - Spray Base samples \\
40 & 112 & \\
45 & 115 & Excessive foaming - Spray Base samples \\
47 & 117 & No reaction observed - NPH samples \\
61 & 125 & \\
\hline
\end{tabular}

Sample Composition:

$2 \mathrm{ml}$ of $1 \underline{\mathrm{M}} \mathrm{U}$ or $1 \underline{\mathrm{M}} \mathrm{Th}$ in Thorex

$1 \mathrm{ml}$ of test diluent (Chevron 450 Spray Base or NPH) 
TABLE 2

TBP/DILUENT NITRATION STUDY - DATA SUMMARY A

\begin{tabular}{|c|c|c|}
\hline $\begin{array}{l}\text { Time } \\
\text { (min) }\end{array}$ & $\begin{array}{c}\text { Temperature } \\
\left({ }^{\circ} \mathrm{C}\right)\end{array}$ & Observation \\
\hline 0 & 138 & \\
\hline 3 & 125 & Foaming and $\mathrm{NO}_{2}$ Tubes 3 and 5 \\
\hline 6 & 119 & \\
\hline 18 & 116 & \\
\hline 24 & 118 & \\
\hline 29 & 120 & \\
\hline 34 & 122 & \\
\hline 41 & 127 & Excessive foaming Tubes 3 and 5 \\
\hline 52 & 133 & \\
\hline 59 & 137 & \\
\hline 68 & 145 & \\
\hline 73 & 150 & Organic layer turbid Tube 4 \\
\hline 80 & 153 & Incipient foaming Tube 4 \\
\hline 92 & 180 & \\
\hline 94 & 185 & \\
\hline 104 & 197 & \\
\hline
\end{tabular}

Initial Temperature: $138^{\circ} \mathrm{C}$.

Sample Composition:

Tube $12 \mathrm{~m} 11$ M Th-Thorex solution only

Tube $22 \mathrm{ml} 1$ M Th-Thorex solution $+1.0 \mathrm{ml} \mathrm{30 \%} \mathrm{TBP/NPH}$

Tube $32 \mathrm{ml} 1$ M Th-Thorex solution $+1.0 \mathrm{ml} \mathrm{30 \%} \mathrm{TBP} / \mathrm{S}$. Base

Tube $42 \mathrm{ml} 1$ M Th-Thorex solution $+1.0 \mathrm{ml} 30 \% \mathrm{TBP} / \mathrm{NPH}$

Tube $52 \mathrm{ml} 1 \mathrm{M}$ Th-Thorex solution $+1.0 \mathrm{ml} \mathrm{30 \%} \mathrm{TBP} / \mathrm{S}$. Base 


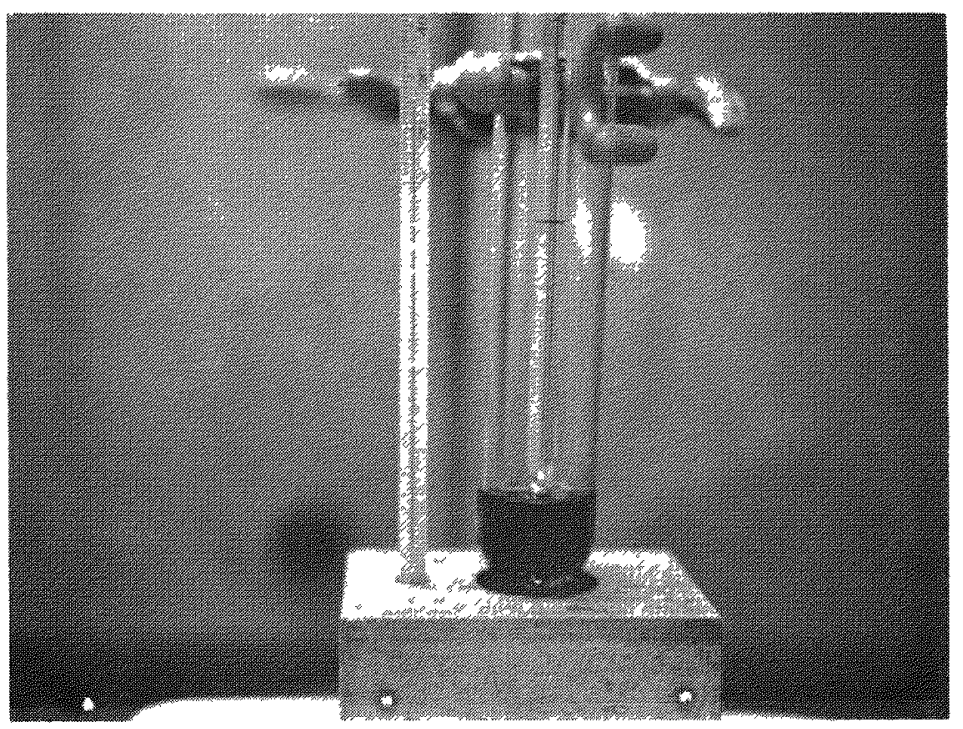

Fig. 3. Aluminum block-glass cup heating apparatus 
hydrocarbons (commercially available materials furnished through the courtesy of Allied General Nuclear Services from inventory - see Table C in the Appendix), as well as the previously mentioned diluents. Data obtained for these tests appear in Table 3 .

No rapid, exothermic reactions were observed during these tests. Slow evolution of $\mathrm{NO}_{2}$, however, was observed in all tests performed, and incipient $\mathrm{NO}_{2}$ evolution occurred at a lower temperature with Chevron Deodorized Spray Base Solvent 450 than with NPH.

A photograph of some of the organic layers resulting from these tests appears as Fig. A-1 in the Appendix. The varying degree of solvent degradation as a function of diluent is evident in Fig. A-1.

\subsection{REFLUX EXPERIMENTS}

Initial experimentation at General Atomic Company revealed the NPH diluent to be more resistant to nitration than a previously used naphthenictype solvent (Shell Deodorized Spray Base). To verify this finding, reflux experiments were performed under literature conditions reported to produce "red-oil" (Ref. 8). These experiments consisted of refluxing $200 \mathrm{ml}$ of 1.1 M nitric acid containing 0.1 M uranyl nitrate or thorium nitrate (b.p. $=101^{\circ} \mathrm{C}$ ) with $25 \mathrm{~m} 1$ of $30 \% \mathrm{TBP} / \mathrm{diluent}$ for 72 hours. "Red-oi1" formation was observed only in organic phases containing the naphthenic-type diluent and was formed in both thorium and uranyl nitrate heavy metal systems. Additional reflux experiments demonstrated "red oil" was not formed in systems containing NPH diluent under conditions more extreme than described above (aqueous concentrations to 1 M heavy meta1 and 6.5 M nitric acid, boiling at $113^{\circ} \mathrm{C}$ )

As further evidence of the nitration susceptibility of the naphthenictype diluent, an infrared spectrogram is given in Fig. 4. A "red-oil" sample derived from Chevron Deodorized Spray Base Solvent 450, as described above, was prepared for the spectral analysis by water washing to remove 
TABLE 3

TBP/DILUENT NITRATION STUDY - DATA SUMMARY B

\begin{tabular}{|c|c|c|c|c|}
\hline System $^{(a)}$ & $\begin{array}{c}\text { Aluminum Block } \\
\text { Temperature } \\
\left({ }^{\circ} \mathrm{C}\right)\end{array}$ & $\begin{array}{l}\text { Temperature } \\
\text { Incipient } \mathrm{NO}_{2} \\
\text { Evolution } \\
\left({ }^{\circ} \mathrm{C}\right)\end{array}$ & $\begin{array}{c}\text { Final } \\
\text { Temperature } \\
\left({ }^{\circ} \mathrm{C}\right)\end{array}$ & $\begin{array}{c}\text { Time Elapsed } \\
\text { Insertion-Final } \\
\text { Temperature } \\
\text { (min) }\end{array}$ \\
\hline $30 \%$ TBP/Chev. S. Base/Th & 175 & 77 & 171 & 6.5 \\
\hline $30 \% \mathrm{TBP} /$ Chev. S. Base/U & 175 & 109 & 170 & 8.5 \\
\hline $30 \% \mathrm{TBP} / \mathrm{So}$. Hamp. NPH/Th & 175 & 109 & 159 & 6.5 \\
\hline $30 \% \mathrm{TBP} / \mathrm{So}$. Hamp. NPH/U & 175 & 129 & 158 & 6.5 \\
\hline $30 \% \mathrm{TBP} /$ Conoco NPH/Th & 175 & 121 & 150 & 7.0 \\
\hline $30 \% \mathrm{TBP} / \mathrm{Texaco} \mathrm{NPH} / \mathrm{Th}$ & 175 & 122 & 159 & 7.0 \\
\hline
\end{tabular}

(a) Prior to test, organic phase was equilibrated with 1 M Th/U-Thorex solution. 


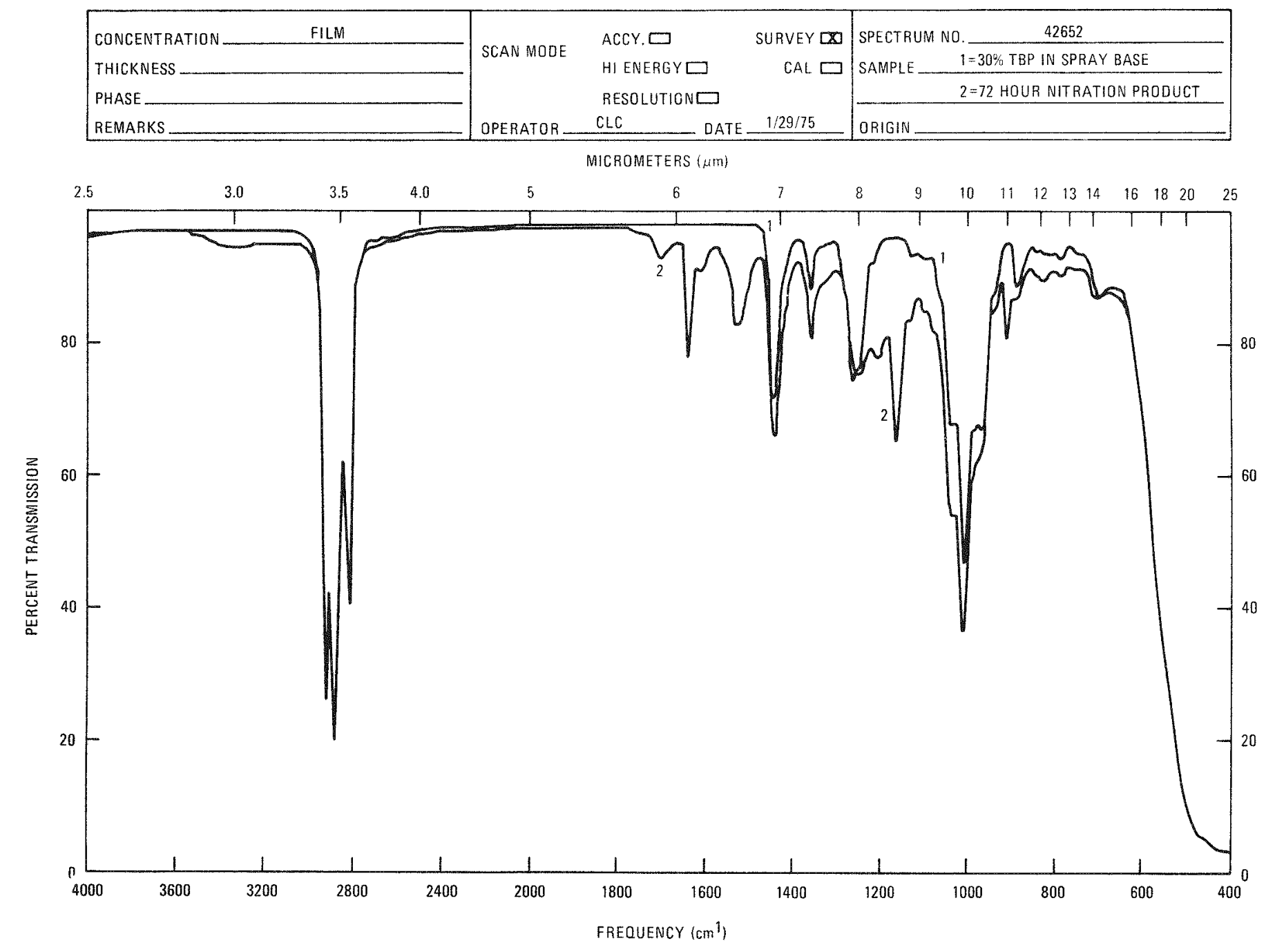

Fig. 4. Infrared spectrogram 
thorium nitrate and nitric acid. The original 30\% TBP/Spray Base infrared scan is included in Fig. 4 for reference. The additional regions of infrared absorption for the "red-oil" sample generally correspond to nitro substitution in organic compounds.

\subsection{SIMULATED CONCENTRATOR EXPERIMENTS}

Chemical analyses of a typical pilot plant intercycle concentrator product solution (ITC) gave a composition of $1.43 \mathrm{M} \mathrm{Th}^{+4}$ and $3.50 \mathrm{M} \mathrm{H}^{+}$. The boiling point of the typical ITC solution was determined to be $112^{\circ} \mathrm{C}$. An aqueous solution of the above composition was prepared from reagent grade thorium-nitrate tetrahydrate and nitric acid and was used for all experiments described in this section. Two organic solutions were prepared for static flooding and continuous addition tests; these were composed of $30 \%$ TBP by volume dissolved in South Hampton Company NPH and Chevron Deodorized Spray Base Solvent 450, respectively.

\subsubsection{Simulated Thorium Intercycle Concentrator Operation - Organic Static Flooding Tests}

A drawing of the apparatus used for organic static flooding tests appears as Fig. 5.

In these tests, an amount of TBP/diluent solution to yield a TBP/ thorium nitrate weight ratio of $0.15^{*}$ was added to a simulated ITC solution, which had its boiling point adjusted by evaporation to a predetermined temperature prior to operation under reflux. Thorium intercycle concentrator bottom solutions with boiling points greater than $\sim 118^{\circ} \mathrm{C}$ would result only during maloperation of a thorium intercycle concentrator. Following addition of the organic solution, the system was allowed to reflux for several hours to monitor (a) the occurrence of a vigorous reaction, and (b) the formation of "red-oil" (evidence of solvent nitration).

*This ratio was selected because work at Hanford (Ref. 8) indicated a minimum critical ratio of 0.15 for vigorous reactions with the TBP/urany 1 nitrate system. 


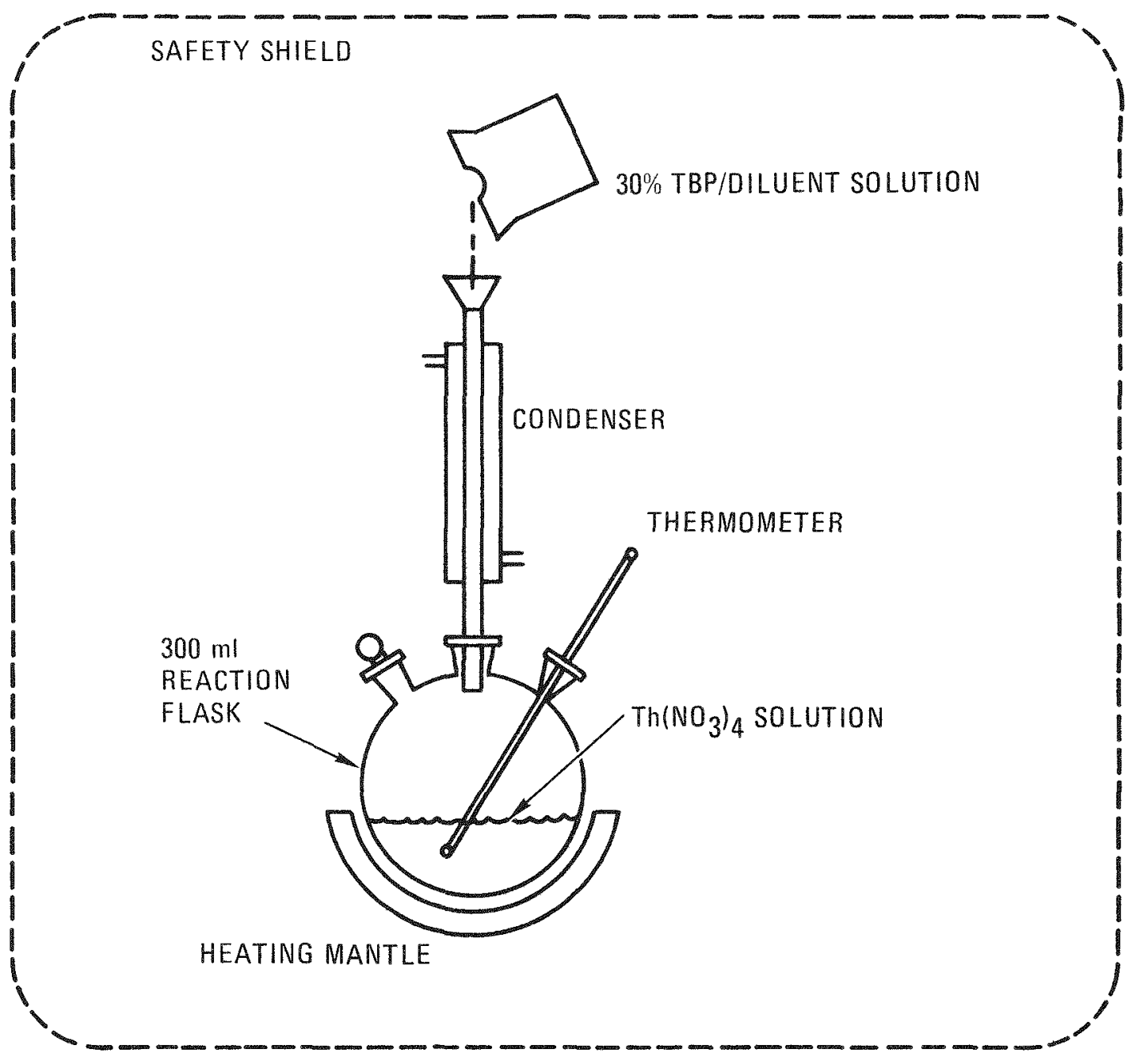

Fig. 5. Experimental apparatus for static organic flooding tests 
Experimental data obtained and observations recorded during static flooding tests are presented in Tables 4 and 5.

No vigorous reactions were observed in tests with either the South Hampton Company NPH or Chevron Deodorized Spray Base Solvent 450 system. Slow evolution of $\mathrm{NO}_{2}$ was observed in all tests performed. The presence of "red-oil" was noted in all tests in which Chevron Deodorized Spray Base Solvent 450 was used as a diluent. A slight red organic phase coloration was noted for the NPH diluent system only after twelve hours of refluxing at $150^{\circ} \mathrm{C}$. A photograph of typical reaction products from these tests is given in Fig. A-2 in the Appendix.

\subsubsection{Simulated Thorium Intercycle Concentrator Operation - Continuous Organic Addition Tests}

A drawing and a photograph of the apparatus used for continuous organic flooding tests appear as Figs. 6 and 7, respectively.

The aqueous solution described above was heated to $135^{\circ} \mathrm{C}$ to simulate thorium intercycle product overconcentration which could occur during maloperation of a thorium intercycle concentrator. On attainment of $135^{\circ} \mathrm{C}$, $30 \%$ by volume TBP/diluent was added to the boiler pot at a rate of 0.42 $\mathrm{ml} / \mathrm{min}$ with a metering pump (FMI RPIG 50). The total volume of $30 \% \mathrm{TBP} /$ diluent added was $25.2 \mathrm{ml}$, which is equivalent to a TBP/thorium nitrate weight ratio of 0.23 .

In continuous organic addition experiments, no vigorous reactions occurred at $135^{\circ} \mathrm{C}$. Examination of boiler pot contents following continuous operations revealed "red-oil" formation only in tests employing Chevron Deodorized Spray Base Solvent 450.

*This ratio is considerably in excess of the 0.15 critical ratio for vigorous reactions found in earlier work (Ref. 8). 
TABLE 4

SYSTEM TBP/CHEVRON SPRAY BASE - STATIC FLOODING TESTS - DATA SUMMARY

\begin{tabular}{|c|c|c|c|c|c|c|}
\hline $\begin{array}{c}\text { Test } \\
\text { No. }\end{array}$ & $\begin{array}{c}\text { Boiling Point } \\
\text { Aqueous } \\
\text { Solution } \\
\left({ }^{\circ} \mathrm{C}\right)\end{array}$ & $\begin{array}{l}\text { Total Initial } \\
\text { Vol. Aqueous } \\
\text { Solution (a) } \\
\text { (m1) }\end{array}$ & $\begin{array}{l}\text { Time Period } \\
\text { for Organic } \\
\text { Addition } \\
\text { (min) }\end{array}$ & $\begin{array}{c}\text { Tota1 Vol. } \\
\text { 30\% TBP/ } \\
\text { S. Base Added } \\
\text { (m1) }\end{array}$ & $\begin{array}{l}\text { Total } \\
\text { Reflux } \\
\text { Time } \\
\text { (hr) }\end{array}$ & Observation (b) \\
\hline 1 & 118 & 67.5 & 10 & 10 & 12 & A \\
\hline 2 & 125 & 67.5 & 15 & 10 & 16 & $B$ \\
\hline 3 & 135 & 101.3 & 20 & 15 & 8.5 & $\mathrm{C}$ \\
\hline 4 & 150 & 101.3 & 20 & 15 & 4.25 & $\mathrm{D}$ \\
\hline
\end{tabular}

(a) Initial aqueous composition $=1.38 \mathrm{M} \mathrm{Th}^{+4}, 3.37 \mathrm{M} \mathrm{H}^{+}$.

(b) A11 organic layers had red colorations. The color intensity increased directly as a function of temperature. The $\mathrm{NO}_{2}$ evolution rate appeared to decrease with increasing temperature and may be due to decreasing free acidity at higher temperatures.

A Considerable $\mathrm{NO}_{2}$ evolution. No foaming.

$B$ Considerable $\mathrm{NO}_{2}$ evolution. No foaming.

C $\mathrm{NO}_{2}$ evolution. Some evidence of foaming.

D $\mathrm{NO}_{2}$ evolution. Some evidence of foaming. Boiling point (constant) of aqueous layer dropped to $135^{\circ} \mathrm{C}$ by end of reflux period (due possibly to lower boiling point of the denitrated salt). 
TABLE 5

SYSTEM TBP/NPH - STATIC FLOODING TESTS - DATA SUMMARY

\begin{tabular}{|c|c|c|c|c|c|c|}
\hline $\begin{array}{c}\text { Test } \\
\text { No. }\end{array}$ & $\begin{array}{c}\text { Boiling Point } \\
\text { Aqueous } \\
\text { Solution } \\
\left({ }^{\circ} \mathrm{C}\right)\end{array}$ & $\begin{array}{l}\text { Total Initial } \\
\text { Vol. Aqueous } \\
\text { Solution (a) } \\
(\mathrm{ml})\end{array}$ & $\begin{array}{l}\text { Time Period } \\
\text { for Organic } \\
\text { Addition } \\
\text { (min) }\end{array}$ & $\begin{array}{l}\text { Total Vol. } \\
30 \% \text { TBP/NPH } \\
\text { Added } \\
\text { (m1) }\end{array}$ & $\begin{array}{l}\text { Total } \\
\text { Reflux } \\
\text { Time } \\
\text { (hr) }\end{array}$ & Observation (b) \\
\hline 1 & 112 & 67.5 & 5 & 10 & 19.5 & A \\
\hline 2 & 117 & 67.5 & 5 & 10 & 16.0 & B \\
\hline 3 & 124 & 67.5 & 5 & 10 & 18.75 & $\mathrm{C}$ \\
\hline 4 & 130 & 101.2 & 10 & 15 & 14.75 & $\mathrm{D}$ \\
\hline 5 & 135 & 101.2 & 15 & 15 & 13.5 & $\mathrm{E}$ \\
\hline 6 & 150 & 101.2 & 5 & 15 & 12.0 & $F$ \\
\hline
\end{tabular}

(a) Initial aqueous composition $=1.38 \underline{\mathrm{M}} \mathrm{Th}^{+4}, 3.37 \mathrm{M} \mathrm{H}^{+}$.

(b) Only the organic layer from Test 6 had a slight red coloration. The $\mathrm{NO}_{2}$ evolution rate appeared to decrease with increasing temperature and may be due to decreasing free acidity at higher temperatures.

A Slow $\mathrm{NO}_{2}$ evolution throughout reflux period. No foaming.

B $\mathrm{NO}_{2}$ evolution more rapid than Test 1. Gelatinous ppt observed on return to ambient temperature. It is speculated that ppt is a reaction product of thorium and TBP hydrolysis products. No foaming.

C $\mathrm{NO}_{2}$ evolution. No foaming.

D $\mathrm{NO}_{2}$ evolution. No foaming.

$\mathrm{E} \mathrm{NO}_{2}$ evolution. Boiling point (constant) of aqueous layer dropped to $122^{\circ} \mathrm{C}$ by end of reflux period.

F Slow $\mathrm{NO}_{2}$ evolution. Boiling point (constant) of aqueous layer dropped to $135^{\circ} \mathrm{C}$ by end of reflux period. 


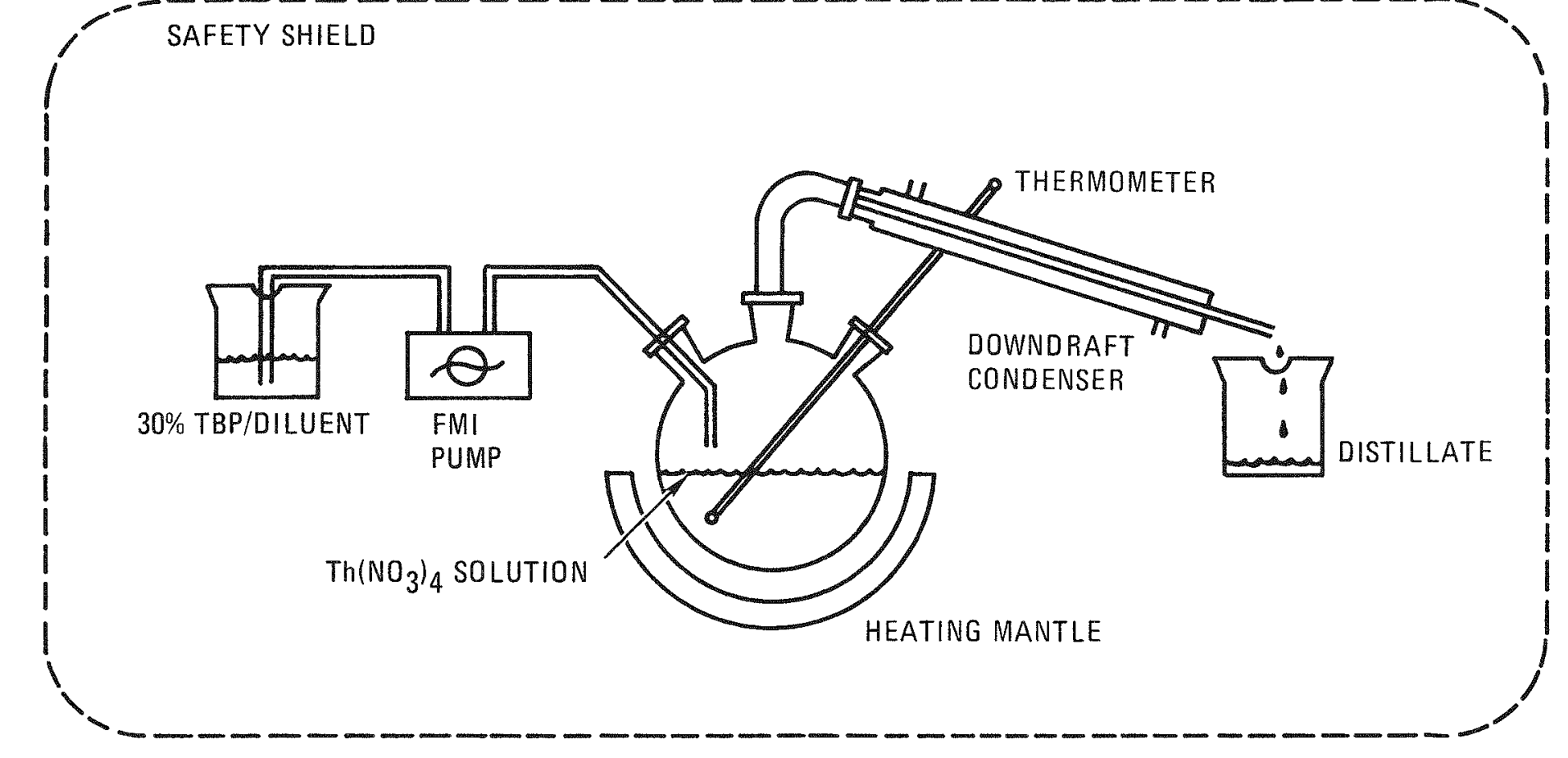

Fig. 6. Experimental apparatus for continuous organic addition tests 


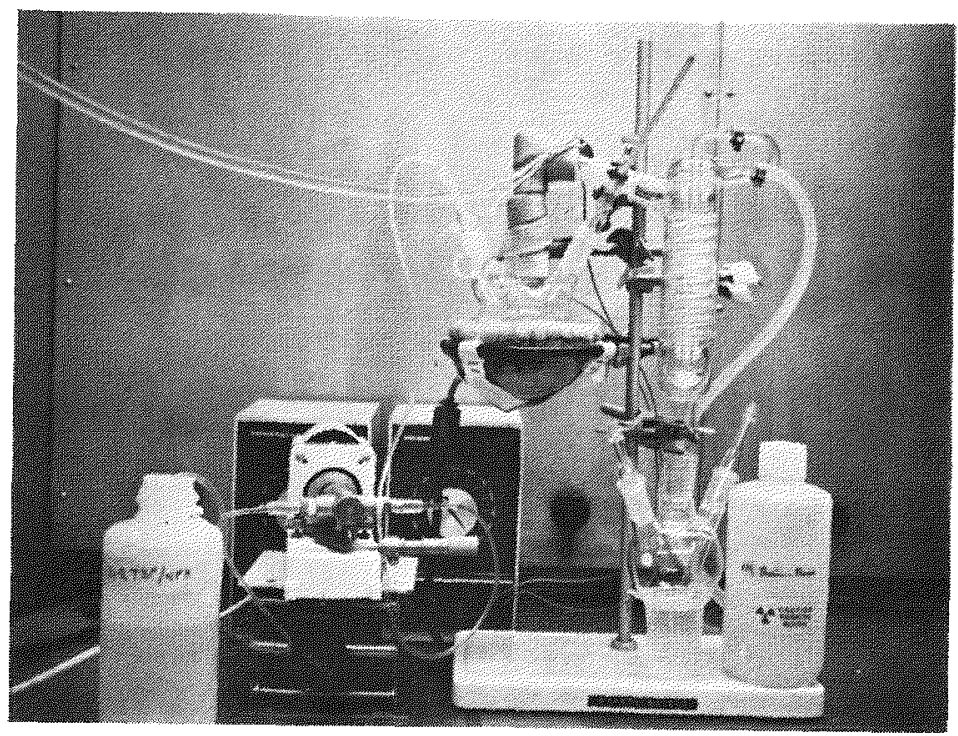

Fig. 7. Experimental apparatus for continuous organic flooding tests 


\section{CONCLUSIONS}

Bench-scale experimentation conducted at General Atomic Company has given no evidence to support the existence of an undue safety hazard in the planned operation of the heavy metal concentrators in the Acid-Thorex flowsheet. Also, no vigorous, exothermic reactions were encountered in tests designed to simulate concentrator maloperations (temperatures to $150^{\circ} \mathrm{C}$ ) with South Hampton and Conoco NPH or Chevron Deodorized Spray Base Solvent 450. Test results indicate operation of a heavy metal nitrate concentrator with she 11 temperatures to $150^{\circ} \mathrm{C}$ (with attendant increase in effective $\Delta \mathrm{T}$, which controls the heat transfer to the solution and thus the evaporation rate) is permissible provided adequate safety factors are incorporated in the design of the concentrator. These safety factors would include the following:

1. Use of a nitration-resistant diluent, e.g., South Hampton, Conoco, or Texaco NPH.

2. A maximum allowable steam chest temperature of $150^{\circ} \mathrm{C}$.

3. Incorporation of design safeguards to prevent (a) concentrator deentrainment tower plugging and resultant pressure buildup and (b) organic flooding of the concentrator with a resultant TBP/ thorium nitrate weight ratio in excess of 0.15 at $150^{\circ} \mathrm{C}(0.23$ at $\left.135^{\circ} \mathrm{C}\right)$.

In addition to improving heavy meta1 - fission product DFs, use of the nitration diluent, NPH, has significantly reduced the hazard potential of heavy metal concentrator operations. 


\section{RECOMMENDED FUTURE STUDY}

Additional tests should be conducted at atmospheric pressure to determine whether a minimum critical weight ratio for vigorous reactions exists for the thorium nitrate-TBP/NPH system as a function of temperature. The present work has shown the minimum critical thorium nitrate/TBP weight ratio to be $>0.23$ at $135^{\circ} \mathrm{C}$ and $>0.15$ at $150^{\circ} \mathrm{C}$. Also, a study of the nitration behavior of uranium/thorium - solvent systems during heating under pressure greater than atmospheric is suggested. 


\section{REFERENCES}

1. Long, J. T., Engineering for Nuclear Fuel Reprocessing, Gordon and Breach Science Publishers, New York, 1967, p. 196.

2. Long, J. T., Engineering for Nuclear Fuel Reprocessing, Gordon and Breach Science Publishers, New York, 1967, p. 207.

3. Pollock, H., "A Stable Diluent for Purex Process Extractants," E. I. Dupont \& Co., Savannah River Laboratory, DP-294, June 1958.

4. Beary, M. M., "Solvent Improvement Resulting From the Use of NPH in the Hanford Purex Plant," Atlantic Richfield Hanford Company, ARHSA-73, June 12, 1970.

5. Colven, T. J., G. M. Nichols, and T. H. Siddall, "TNX-Evaporator Incident," E. I. DuPont \& Co., Savannah River Laboratory, DP-25, May 15, 1953.

6. Sege, G., "Overconcentration in Initial Operation of Uranium Evaporator-231 Building," Hanford Laboratories, HW-28690, July 10, 1953.

7. Shefcik, J. J., "Safety Aspects of Purex P1ant Concentrator Operation," Hanford Laboratories, HW-40556, December 23, 1955.

8. Wagner, R. M., "Investigation of Explosive Characteristics of Purex Solvent Decomposition (Red Oil)," Hanford Laboratories, HW-27492, March 17, 1953.

9. Eakin, D. E., "Hazardous Properties of Purex Plant Chemicals," Atlantic Richfield Hanford Company, ARH-1404, October 15, 1969.

10. Pugh, R. A., "Notes Pertaining to Recuplex Product Evaporation," Hanford Laboratories, HW-32100, April 28, 1954.

11. "Purex Technical Manua1," Chemical Development Subsection, Separations Technology Section, Engineering Department, Hanford Laboratories, HW-31000, March 25, 1955.

12. Spaunburgh, R. G., Allied General Nuclear Services, private communication. 
APPENDIX 


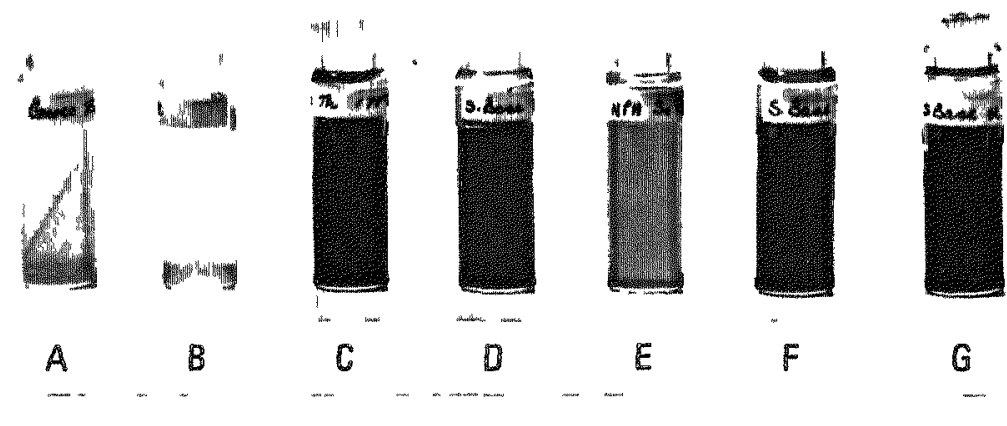

Final

$\underline{\text { Sample }}$

A

System Composition

TBP/ Conoco - Thorium Nitrate

Temperature ${ }^{\circ} \mathrm{C}$

150

159

C TBP/Chevron S. Base - Thorium Nitrate 171

D TBP/Chevron S. Base - Thorium Nitrate 128

E TBP/South Hampton - Uranyl Nitrate 158

F TBP/Chevron S. Base - Uranyl Nitrate 143

G TBP/Chevron S. Base - Thorium Nitrate 160

Fig. A-1. Representative degraded solvent test products 

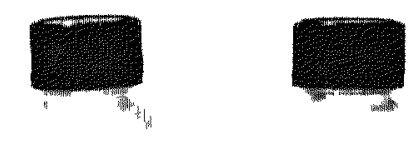

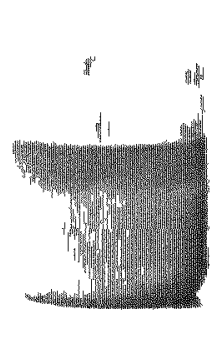

A

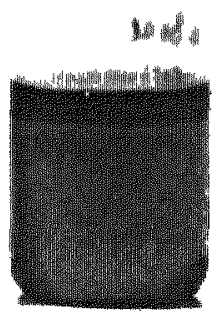

B

Final

Sample

System Composition

A

TBP/NPH - Thorium Nitrate

Temperature ${ }^{\circ} \mathrm{C}$

B

TBP/S. Base - Thorium Nitrate

150

150

Fig. A-2. Typical reaction products from organic static flooding tests 
TABLE A

PROPERTIES OF DILUENTS (a)

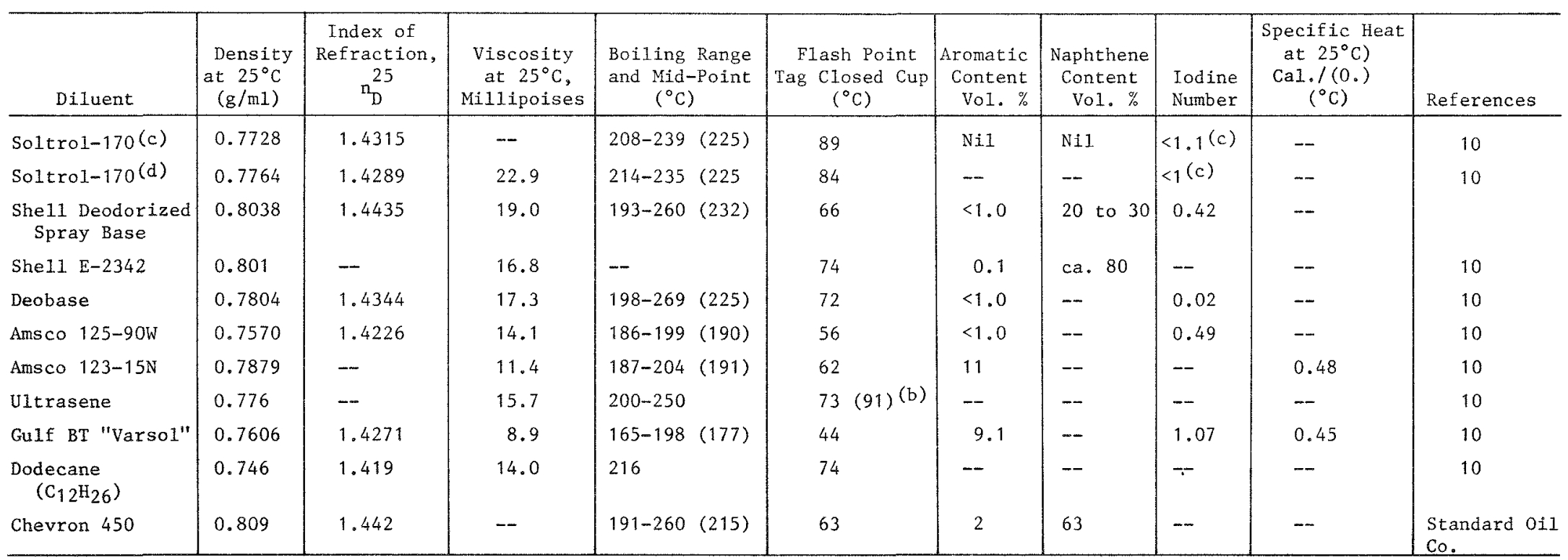

(a) The properties of commercial diluents are subject to slight variations from batch to batch. The data tabulated represent typical values for the indicated diluents.

(b) After washing with water. The Cleveland closed cup flash point is $84^{\circ} \mathrm{C}$.

(c) properties as cited by manufacturer [see Note (a)].

(d) Properties as determined on one sample at H.A.P.O. [see Note (a)].

Source: See Reference No. 11. 
TABLE B

NORMAL PARAFFIN HYDROCARBON - SPECIFICATIONS

N-paraffin hydrocarbon

$\mathrm{C}_{10}$ to $\mathrm{C}_{14}$ components

Aromatics as $1,2,3,4-$ tetrahydronaphthalene

Iodine number (olefins as wt. \% 1-tetradecene)

Alcohol

Sp. Gr. $20 / 20^{\circ} \mathrm{C}$

Viscosity a $25^{\circ} \mathrm{C}$

Flash point
Min. 98 vol. \%

Min, 99 vo1, \%

Max. 0.2 wt. \%

Max, 0.1 wt. \%

Max. 0.05 wt. \%

$\operatorname{Max} .0 .76$

Max. 1.8 Centipoise

$70^{\circ} \mathrm{C}$ 
TABLE C

NORMAL PARAFFIN HYDROCARBON PROPERTIES

\begin{tabular}{|c|c|c|c|c|}
\hline & \multicolumn{2}{|c|}{ Conoco $\mathrm{C}_{12} \mathrm{C}_{14}$} & \multicolumn{2}{|c|}{ Texaco $\mathrm{P}-4$} \\
\hline & Spex & AGNS Analysis & Spex & AGNS Analysis \\
\hline $\mathrm{C}_{10}$ and 1ighter & -- & $<0.2$ wt. $\%$ & -- & $<0.1$ \\
\hline $\mathrm{C}_{11}$ and lighter & $2.0 \% \operatorname{Max}$. & 0.8 wt. $\%$ & -- & 0.5 \\
\hline $\mathrm{C}_{12}$ & $10 \pm 5 \%$ & 8.5 wt. $\%$ & $8-15 \%$ & 8.5 \\
\hline $\mathrm{C}_{13}$ & 50 Min. & 58.1 wt. $\%$ & $45-50 \%$ & 48.5 \\
\hline $\mathrm{C}_{14}$ & $30-45 \%$ & 32.4 wt. $\%$ & $30-45 \%$ & 40.9 \\
\hline $\mathrm{C}_{15}$ and higher & $2.0 \operatorname{Max}$ & $<0.2$ wt. $\%$ & - & 1.5 \\
\hline $\mathrm{C}_{16}$ & -- & -- & -- & 0.2 \\
\hline $\mathrm{C}_{17}$ or greater & -- & - & -- & $<0.1$ \\
\hline $\begin{array}{l}\text { Total N- } \\
\quad \text { Paraffin }\end{array}$ & 97.5 Min. & -- & 98\% Min. & -- \\
\hline Aromatics & $0.6 \mathrm{Max}$. & $0.27 \%$ & $0.5 \%$ Max. & $0.42 \%$ \\
\hline Bromine index & $200 \operatorname{Max}$. & $<20(\mathrm{mg} / 100 \mathrm{~g})$ & 100 Max. & $<20 \quad(\mathrm{mg} / 100 \mathrm{~g})$ \\
\hline Sulfur, ppm & 10 Max. & - & 5 ppm Max. & -- \\
\hline
\end{tabular}

Specific Gravity

$16 \% \mathrm{C}$

0.763.

Flash, pt.

(Pensky-Martens) $--96^{\circ} \mathrm{C}$.

Source of table: Ref. 12 . 